\title{
Prevalence and Risk Factors of Peripheral Neuropathy among Diabetic Patients in Aden Diabetic Center
}

\author{
BALQIS A. ABDULLA EBRAHIM, M.D.*; LINDA MUSTAFA H. BA ALWI, M.Sc.* and \\ HANAN Sh. MOHAMMED, M.D.** \\ The Departments of Internal Medicine, Faculty of Medicine, Aden University, Yemen* and Assiut University**, Egypt
}

\begin{abstract}
Background: Diabetic Peripheral Neuropathy (DPN) is an important micro-vascular complication of Diabetes Mellitus (DM), considered as a major contributor to foot ulceration and lower limb amputation among diabetic patients and have remarkable negative effect on patient's quality of life.

Aim of Study: This study aimed to estimate the prevalence and possible risk factors of DPN among patients attending diabetic center in Aden governorate, Yemen.

Patients and Methods: This cross-sectional retrospective study review prevalence of peripheral neuropathy among patients aged 18-70 years with type 1 and 2 DM (T1D, T2D), were 124 patients assessed by neurosymptoms and neurodisability scores (NSS and NDS respectively). Descriptive statistic and logistic regression analysis were done.

Results: The prevalence of DPN based on NSS and NDS was $60.48 \%$. Risk factors significantly associated with DPN were age ( $p 0.015)$, educational level $(p 0.013)$, type 2 diabetes $(p 0.022)$, and duration of diabetes $(p 0.001)$, dyslipidemia ( $p 0.009)$, abdominal obesity ( $p 0.001)$, body mass index ( $p$ $0.036)$ and retinopathy $(p 0.035)$. Female gender, hypertension, elevated glycated hemoglobin and the presence of albuminuria were associated with higher frequency of DPN although this relation was statistically non-significant. Logistic regression analysis revealed that Illiteracy (OR 8.75, 95\% CI 2.2334.33 ), dyslipidemia (OR 1.97, 95\% CI 1.04-24.44), long standing of diabetes (OR 1.14, 95\% CI 1.05-1.23), and abdominal obesity (OR 1.05, 95\% CI 1.01-1.09) were significantlly associated with DPN.
\end{abstract}

Conclusions: A higher prevalence was observed with illiteracy, dyslipidemia, longer duration of diabetes and abdominal obesity.

Key Words: Diabetic peripheral neuropathy - PrevalenceRisk factors.

\section{Introduction}

DIABETES Mellitus (DM) is a complex metabolic disorder that is manifested by chronic hyperglyc-

Correspondence to: Dr. Balqis A. Abdulla Ebrahim, The Department of Internal Medicine, Faculty of Medicine, Aden University, Yemen emia. It results in disturbances of carbohydrate, fat and protein metabolism as a consequence of defects in insulin secretion, insulin action, or both. Diabetic progression leads to severe diabetes complications such as retinopathy, neuropathy, nephropathy, cardiovascular complications and ulceration [1].

Chronic peripheral sensorimotor symmetrical neuropathy accounts for approximately $75 \%$ of the diabetic neuropathies [2]. It is defined as the presence of symptoms and/or signs of peripheral nerve dysfunction in people with DM, after exclusion of other causes [3]. The primary symptom of DPN is loss of sensation in the toes, which extends to involve the feet and leg in a stocking distribution. Some patients complain about numbness and pain, but most frequently the disease progresses insidiously and undetected. If no action is taken, foot callus, ulceration and infection might develop and further turn into distressing and painful impairment. The foot ulcers among diabetic patients are mostly of neuropathic origin, and therefore eminently preventable [4].

Neuropathy and neuropathic pain are among the strongest determinants of reduced health-related quality of life in patients with type 2 diabetes mellitus. Also, neuropathy management including adequate podiatric care in patients with type 2 diabetes mellitus adds on to the economic burden of the national health system [5].

Different mechanisms have been implicated in the development of diabetic neuropathy. The most important initiator of the process is probably hyperglycemia. Mechanisms of glucose neurotoxicity include accumulation of sorbitol via the enzyme aldolase reductase and glucose driven oxidative stress subsequently leading to structural changes 
[6]. Several risk factors have been identified for neuropathy including age, duration of diabetes and the poor glycemic control, while cigarette smoking, retinopathy, hypertension, obesity, hyperlipidemia and micro-albuminuria has been pointed out as potential risk indicators [7]

Various clinical composite scores have been developed to assess DPN. These include Neuropathy Symptom Score (NSS), Diabetic Neuropathy Examination (DNE), Neuropathy Disability Score (NDS), Michigan Neuropathy Screening Instrument (MNSI) and Total Symptom Score (TSS) [8]. The reliability of scoring symptoms and clinical findings in patients with suspected peripheral neuropathy can be high if the examiner is well trained and the scales are well defined [9]

The gold standard for detecting DPN is the nerve conduction velocity. It can diagnose sensory and motor losses due to neuropathy even when dysfunction is subclinical, and it can predict ulceration and mortality in diabetic patients. However, it is not commonly available in public health units [10].

\section{Patients and Methods}

Around six months duration, during the period from January to June 2015. The present retrospective cross-sectional study was carried out on 124 diabetic patients conducted an outpatient setting of diabetic center in Aden governorate, Yemen to estimate the prevalence and possible risk factors of DPN. Data collected from patient's full medical records were selection considered to be of both types of diabetic (insulin and non-insulin dependent) with 5-20 years duration of diabetes. Measurement of blood pressure, waist circumference, BMI, and ophthalmologic examination which evaluated by fundoscopy. Para clinical investigations included Fasting Blood Sugar (FBS), Glycated hemoglobin $\left(\mathrm{HbA}_{1_{c}}\right)$, renal function test (urea and creatinine), lipid profile, electrocardiogram, 24-h protein excretion ( $\geq 500 \mathrm{mg} /$ day), urine for albuminuria and urine Albumin Creatinine Ratio (UACR). Diabetic Peripheral Neuropathy (DPN) involving distal limbs (after the exclusion of other causes) was assessed by clinical peripheral neuropathy scoring systems (neuropathy symptoms and disability scoring). Neuropathy symptom score NSS (5 questions) assigning points symbolized by $2 \mathrm{p}, 1 \mathrm{p}, 0 \mathrm{p}$ were total maximum abnormal symptom score was 9 points (3-4 mild, 5-6, moderate and 7-9 sever) and neuropathy disability score NDS (4 tests) symbolized by $2 \mathrm{p}, 1 \mathrm{p}, 0 \mathrm{p}$ were total maximum abnormal disability score was 10 points (3-5 mild,
6-8 moderate and 9-10 sever) in which the minimum acceptable criteria for diagnosis of diabetic peripheral neuropathy included moderate disability with or without symptoms, or mild disability with moderate symptoms.

Criteria included in this study were patients with diabetes mellitus were diagnosed based on American Diabetic Association criteria, fasting blood sugar of $126 \mathrm{mg} / \mathrm{dl}$ or random blood sugar of $200 \mathrm{mg} / \mathrm{dl}$ or more, or glycated hemoglobin $6.5 \%$ or more. While the excluded criteria were patients with history of familial or inherited neuropathies, alcohol ingestion, patients on dialysis, receiving chemotherapy therapy or other drugs that may cause neuropathy, HIV treatment, hypothyroidism and foot ulcer or imputation.

\section{Statistical analysis:}

Data processing was performed by the computer software program of the Statistical Package for Social Sciences (SPSS) Version 20. Categorical variables were expressed as frequencies, continues variables as mean \pm standard deviation, chi-square to evaluate potential association between categorical variables and student's $t$-test to compare between means. Odds Ratios (OR) with $95 \%$ Confidence Interval (CI) were provided. $p<0.05$ was taken as significant.

\section{Results}

This study included 124 patients with diabetes mellitus conducted at Aden Diabetes Center during the study period from 1 st January to 30 th June 2015. There were $70(56.5 \%)$ female and 54 $(43.5 \%)$ male subjects with age ranges from 18 to 70 years with mean of $51.0 \pm 11.6$ years.

Statistical significant relationship between age and DPN ( $p$ 0.009) were increasing in prevalence of DPN with increased age was observed from $(64 \%)$ in those aged (50-64) years to $(90 \%)$ in those aged $\geq 65$ years. On the other hand; young patients not complicated by DNP aged $<20$ years presented with highest percentage $(100 \%)$. Statistical significant not found in related to the gender and DPN where found slight higher in percentage of affected female patients (64.3\%) Vs. (55.6\%) for males $(p 0.32)$. Illiterate patients showed increasing in percentage $(80.8 \%)$ of DPN, while patients with tertiary level of education had percentage $(62.5 \%)$ without DPN. There was a statistical significant ( $p$ 0.013) of DPN in relation to education level. Social habit (smoker and khat chewing) showed no statistical significant in studied patients with DPN in compare to studied patients without DPN ( $p$ 0.158, 0.077 respectively). 
Table (1): Demographic data and social variables related to DPN.

\begin{tabular}{|c|c|c|c|c|c|c|c|}
\hline \multirow{3}{*}{ Items } & \multicolumn{4}{|c|}{ Peripheral neuropathy } & \multirow{2}{*}{\multicolumn{2}{|c|}{$\begin{array}{c}\text { Total } \\
(\mathrm{n}=124)\end{array}$}} & \multirow{3}{*}{$\begin{array}{c}p- \\
\text { value }\end{array}$} \\
\hline & \multicolumn{2}{|c|}{$\begin{array}{c}\text { Yes } \\
(n=75)\end{array}$} & \multicolumn{2}{|c|}{$\begin{array}{c}\text { No } \\
(n=49)\end{array}$} & & & \\
\hline & No. & $\% \Gamma$ & No. & $\% \mathrm{r}$ & No. & $\%$ & \\
\hline \multicolumn{8}{|l|}{ Age group (years): } \\
\hline$<20$ & 0 & 0.00 & 2 & 100 & 2 & 1.6 & $0.009^{*}$ \\
\hline $20-34$ & 3 & 25.0 & 9 & .70 & 12 & 9.7 & \\
\hline $35-49$ & 18 & 60.0 & 12 & 40.0 & 30 & 24.0 & \\
\hline $50-64$ & 45 & 64.3 & 25 & 35.7 & 70 & 56.5 & \\
\hline$\geq 65$ & & 90.0 & 1 & 10.0 & & 8.0 & \\
\hline Mean age $( \pm \mathrm{SD})$ & \multicolumn{2}{|c|}{$35.65 \pm 9$} & \multicolumn{2}{|c|}{$46.98 \pm 12.8$} & \multicolumn{2}{|c|}{ F 10.0} & $\underline{p} 0.015$ \\
\hline \multicolumn{8}{|l|}{ Gender: } \\
\hline Male & 30 & 55.6 & 24 & 44.4 & 54 & 43.5 & 0.324 \\
\hline Female & 45 & 64.3 & 25 & 35.7 & 70 & 56 & \\
\hline \multicolumn{8}{|l|}{ Education level: } \\
\hline Illiterate & 21 & 80.8 & 5 & 19.2 & 26 & 21 & $0.013 *$ \\
\hline Read and write & 9 & 69.2 & 4 & 30.8 & 13 & 10.4 & \\
\hline Primary education & 20 & 66.7 & 10 & 33.3 & 30 & 24.1 & \\
\hline Secondary education & 13 & 56.5 & 10 & 43.5 & 23 & 18.5 & \\
\hline Tertiary education & 12 & 37.5 & 20 & 62.5 & 32 & 26.0 & \\
\hline \multicolumn{8}{|l|}{ Social habits: } \\
\hline Smoking & 3 & 37.5 & 5 & 62.6 & 8 & 6.5 & 0.158 \\
\hline Khat chewing & 22 & 50.0 & 22 & 50.0 & 44 & 35.5 & 0.077 \\
\hline
\end{tabular}

Table (2): Distribution of studied patients according to diabetic characteristic.

\begin{tabular}{|c|c|c|c|c|c|c|c|}
\hline \multirow{3}{*}{ Items } & \multicolumn{4}{|c|}{$\begin{array}{l}\text { Peripheral } \\
\text { neuropathy }\end{array}$} & \multirow{2}{*}{\multicolumn{2}{|c|}{$\begin{array}{c}\text { Total } \\
(n=124)\end{array}$}} & \multirow{3}{*}{$\underset{\text { value }}{p^{-}}$} \\
\hline & \multicolumn{2}{|c|}{$\begin{array}{c}\text { Yes } \\
(n=75)\end{array}$} & \multicolumn{2}{|c|}{$\begin{array}{c}\text { No } \\
(n=49)\end{array}$} & & & \\
\hline & No. & $\% \mathrm{I}$ & Jo. & $\% \mathrm{I}$ & No. & $\%$ & \\
\hline \multicolumn{8}{|l|}{ Diabetic data: } \\
\hline $\mathrm{T} 1 \mathrm{D}$ & 6 & 35.3 & 11 & 64.7 & 17 & 13.7 & $0.022 *$ \\
\hline T2D & 69 & 64.5 & 38 & 35.5 & 107 & 86.3 & \\
\hline Family history & 55 & 64.7 & 30 & 35.3 & 85 & 68.5 & 0.156 \\
\hline \multicolumn{8}{|l|}{ Duration of diabetes } \\
\hline$<5$ & 19 & 39.6 & 29 & 60.4 & 48 & 38.7 & $0.001 *$ \\
\hline $5-9$ & 20 & 69.0 & 9 & 31.0 & 29 & 23.4 & \\
\hline $10-20$ & 32 & 80.0 & 8 & 20.0 & 40 & 32.3 & \\
\hline$>20$ & 4 & 57.1 & 3 & 42.9 & 7 & 5.6 & \\
\hline Mean duration \pm SD & \multicolumn{2}{|c|}{$9.8 \pm 6.3$} & \multicolumn{2}{|c|}{$6.5 \pm 5.5$} & \multicolumn{2}{|c|}{ F 7.35} & $p 0.008$ \\
\hline \multicolumn{8}{|l|}{ Glycemic control $\mathrm{HbA1}{ }_{c}$ : } \\
\hline Good control & 7 & 41.2 & 10 & 58.8 & 17 & 13.7 & 0.197 \\
\hline Fair control & 32 & 61.5 & 20 & 38.5 & 52 & 41.9 & \\
\hline Poor control & 36 & 65.5 & 19 & 34.5 & 55 & 44.4 & \\
\hline \multicolumn{8}{|l|}{ Type of treatment: } \\
\hline Diet control only & 1 & 50.0 & 1 & 50.0 & 2 & 1.6 & 0.119 \\
\hline Diet + oral & 42 & 58.3 & 30 & 41.7 & 72 & 58.0 & \\
\hline Diet + insulin & 12 & 48.0 & 13 & 52.0 & 25 & 20.2 & \\
\hline Diet + Oral + Insulin & 20 & 80.0 & 5 & 20.0 & 25 & 20.2 & \\
\hline
\end{tabular}

Studied patients with T2DM had a higher prevalence of DPN than studied patient with T1DM $(64.5 \%$ Vs. $35.5 \%)$, such difference was statistically significant ( $p 0.022)$. No statistical significant
(0.156) found in relation to DPN and family history of DM in studied patients, while statistical significant ( $p$ 0.001) found in relation to the duration of DM, where the prevalence of DPN is increased with longstanding DM where found higher among those with duration $10-20$ years $(80 \%)$ and $(60.4 \%)$ with duration $<5$ years among studied patients without DPN. No statistical significant ( $p$ 0.197) found in relation to DPN and $\mathrm{HbA} 1 \mathrm{c}$ among studied patients $(65.5 \%)$, with DPN and poor glycemic control $\mathrm{HbA}_{1 \mathrm{c}}(>9 \%)$ in compare to prevalence of studied patients without DPN (58.8\%) and good glycemic control $(<7 \%)$ there was no statistical significant ( $p 0.119)$ found in relation to DPN and type of diabetic treatment among studied patients, where $(80 \%)$ as high percentage among studied patient with DPN on hypoglycemic and insulin therapy, while (52\%) as high percentage among studied patients with no DPN on insulin therapy.

Table (3): Physical characteristics and peripheral neuropathy of studied patients.

\begin{tabular}{|c|c|c|c|c|c|c|c|}
\hline \multirow{3}{*}{ Clinical data } & \multicolumn{4}{|c|}{ Peripheral neuropathy } & \multirow{2}{*}{\multicolumn{2}{|c|}{$\begin{array}{c}\text { Total } \\
(\mathrm{n}=124)\end{array}$}} & \multirow{3}{*}{$\underset{\text { value }}{p^{-}}$} \\
\hline & \multicolumn{2}{|c|}{$\begin{array}{c}\text { Yes } \\
(\mathrm{n}=75)\end{array}$} & \multicolumn{2}{|c|}{$\begin{array}{c}\text { No } \\
(\mathrm{n}=49)\end{array}$} & & & \\
\hline & No. & $\%$ & No. & $\%$ & No. & $\%$ & \\
\hline \multicolumn{8}{|l|}{$\begin{array}{l}\text {-Abdominal obesity } \\
\text { by waist } \\
\text { circumference: }\end{array}$} \\
\hline Obese & 54 & 74.0 & 19 & 26.0 & 73 & 58.9 & \multirow{2}{*}{$0.000 *$} \\
\hline Non obese & 21 & 41.2 & 30 & 58.8 & 51 & 41.1 & \\
\hline \multicolumn{8}{|l|}{ • $B M I$} \\
\hline Obese & 25 & 67.6 & 12 & 32.4 & 37 & 29.8 & 0.293 \\
\hline Non obese & 50 & 57.5 & 37 & 42.5 & 87 & 70.2 & \\
\hline - Body weight (kg) & \multicolumn{2}{|c|}{$72.1 \pm 14.1$} & \multicolumn{2}{|c|}{$67.6 \pm 13.7$} & \multicolumn{2}{|c|}{$70.3 \pm 14.1$} & 0.077 \\
\hline - Height (cm) & \multicolumn{2}{|c|}{$159.9 \pm 9.7$} & \multicolumn{2}{|c|}{$160.8 \pm 8.2$} & \multicolumn{2}{|c|}{$160.3 \pm 9.1$} & 0.649 \\
\hline - BMI $\left(\mathrm{kg} / \mathrm{m}^{2}\right)$ & \multicolumn{2}{|c|}{$28.25 \pm 5.4$} & \multicolumn{2}{|c|}{$26.19 \pm 5.1$} & \multicolumn{2}{|c|}{$27.43 \pm 5.4$} & $0.036^{*}$ \\
\hline $\begin{array}{l}\text { - Waist } \\
\text { circumference }(\mathrm{cm})\end{array}$ & \multicolumn{2}{|c|}{$99.49 \pm 11.7$} & \multicolumn{2}{|c|}{$91.45 \pm 13.2$} & \multicolumn{2}{|c|}{$96.32 \pm 12.9$} & $0.001 *$ \\
\hline
\end{tabular}

Note: Percentage taken from total of rows. ${ }^{*}$ Chi-square test.

Physical characteristics of studied patients, showed statistical significance $(p 0.000)$ in relation to abdominal obesity in studied patients with DPN (74.0\%) in compare to non-obese studied patients (41.2\%). No statistical significance ( $p$ 0.293) related to BMI and DPN in obese studied patients $(67.6 \%)$ and non-obese studied patients $(57.5 \%)$. The mean of BMI and waist circumference $(28.25 \pm 5.4$, $99.49 \pm 11.7)$ of studied patients with DPN and without DPN $(26.19 \pm 5.1,91.45 \pm 13.2)$ were statistically significant $(p 0.036,0.001)$ in compare to mean of height and weight $(159.9 \pm 9.7,72.1 \pm 14.1)$ of studied patients with DPN and without DPN $(160.8 \pm 8.2,67.6 \pm 13.7)$ were no statistically significant $(0.649,0.077)$. 
Table (4): Laboratory data and peripheral neuropathy of studied patients.

\begin{tabular}{|c|c|c|c|}
\hline \multirow[b]{2}{*}{ Laboratory data } & \multicolumn{2}{|c|}{ Peripheral neuropathy } & \multirow[b]{2}{*}{$\begin{array}{c}p- \\
\text { value }\end{array}$} \\
\hline & $\begin{array}{c}\text { Yes } \\
(n=75) \\
\text { Mean } \pm \text { SD }\end{array}$ & $\begin{array}{c}\text { No } \\
(n=49) \\
\text { Mean } \pm \text { SD }\end{array}$ & \\
\hline Fasting blood glucose (mg/dl) & $174.2 \pm 65.3$ & $169.4 \pm 66.2$ & 0.692 \\
\hline Glycated hemoglobin $\left(\mathrm{HbA} 1_{\mathrm{c}}\right)(\%)$ & $8.89 \pm 1.56$ & $8.52 \pm 1.77$ & 0.226 \\
\hline Serum urea $(\mathrm{mg} / \mathrm{dl})$ & $26.2 \pm 8.4$ & $23.6 \pm 6.8$ & 0.070 \\
\hline Serum creatinine $(\mathrm{mg} / \mathrm{dl})$ & $0.75 \pm 0.22$ & $0.71 \pm 0.16$ & 0.231 \\
\hline Serum total cholesterol (mg/dl) & $193.9 \pm 41.9$ & $195.5 \pm 39.9$ & 0.837 \\
\hline Serum HDL-cholesterol (mg/dl) & $47.3 \pm 11.9$ & $50.8 \pm 20.1$ & 0.223 \\
\hline Serum LDL-cholesterol (mg/dl) & $121.9 \pm 43.9$ & $122.9 \pm 45.3$ & 0.895 \\
\hline Serum triglycerides (mg/dl) & $139.4 \pm 59.5$ & $137.3 \pm 62.0$ & 0.848 \\
\hline
\end{tabular}

Compared laboratory data between patients with and without DPN, where showed that no difference in means of laboratory data (fasting blood sugar, $\mathrm{HbA}_{1 \mathrm{c}}$, serum urea, serum creatinine and lipid profile) as well no statistical significant in relation to studied patients with and without DPN.

Table (5): Comorbidities and peripheral neuropathy among studied patients.

\begin{tabular}{|c|c|c|c|c|c|c|c|}
\hline \multirow{3}{*}{ Clinical data } & \multicolumn{4}{|c|}{ Peripheral neuropathy } & & & \multirow{3}{*}{$\begin{array}{c}p- \\
\text { value }\end{array}$} \\
\hline & \multicolumn{2}{|c|}{$\begin{array}{c}\text { Yes } \\
(n=75)\end{array}$} & \multicolumn{2}{|c|}{$\begin{array}{c}\text { No } \\
(\mathrm{n}=49)\end{array}$} & \multicolumn{2}{|c|}{$\begin{array}{c}\text { Total } \\
(n=124)\end{array}$} & \\
\hline & No. & $\%$ & No. & $\%$ & No. & $\%$ & \\
\hline \multicolumn{8}{|l|}{ Dyslipidemia: } \\
\hline Yes & 45 & 71.4 & 18 & 28.6 & 63 & 50.8 & $0.011 *$ \\
\hline No & 30 & 49.2 & 31 & 50.8 & 61 & 49.2 & \\
\hline \multicolumn{8}{|l|}{ Arterial hypertension } \\
\hline$A H T:$ & 38 & 66.7 & 19 & 33.3 & 57 & 46.0 & 0.194 \\
\hline Yes & 37 & 55.2 & 30 & 44.8 & 67 & 54.0 & \\
\hline \multicolumn{8}{|l|}{ No } \\
\hline Ischemic heart disease & 7 & 53.8 & 6 & 46.2 & 13 & 10.5 & 0.605 \\
\hline IHD: & 68 & 61.3 & 43 & 38.7 & 111 & 89.5 & \\
\hline \multicolumn{8}{|l|}{ Yes } \\
\hline No & & & & & & & \\
\hline
\end{tabular}

Percentage taken from total of rows chi-square test:

Dyslipidemia in studied patients with DPN was with high prevalence (71.4\%) in compare to studied patients without DPN (28.6\%) with significant statistic ( $p$ 0.011). Studied patients with DPN and arterial hypertension $(66.7 \%)$ showed no statistical significance (0.194) in compare to studied patients with DPN and normotensive (55.2\%). Ischemic Heart Disease (IHD) showed no statistical significant ( $p$ 0.605) in studied patients with DPN $(53.8 \%)$ and those without DPN (61.3\%).

Predictors for developing DPN appeared to be significant and independently associated with DPN, were odd ratio in low educational level (8.75 times), dyslipidemia (1.97 times), the duration of diabetes (1.14 times) and waist circumference (1.05 times).
Table (6): Multivariate regression analysis of risk factors for DPN.

\begin{tabular}{lcll}
\hline & \multicolumn{3}{c}{ Statistics } \\
\cline { 2 - 4 } Risk factors & $p$ & OR & \multicolumn{1}{c}{$95 \% \mathrm{CI}$} \\
\hline Age & 0.945 & 0.99 & $0.94-1.06$ \\
Low educational level & 0.002 & 8.75 & $2.23-34.33$ \\
Type of diabetes mellitus & 0.533 & 1.82 & $0.28-11.91$ \\
Duration of diabetes & 0.002 & 1.14 & $1.05-1.23$ \\
Dyslipidemia & 0.041 & 1.97 & $1.04-24.44$ \\
Waist circumference & 0.025 & 1.05 & $1.01-1.09$ \\
Retinopathy & 0.627 & 1.28 & $0.46-3.58$ \\
\hline
\end{tabular}

OR: Odds Ratio.

CI : Confidence Interval.

Table (7): Simple regression analysis of micro vascular complications.

\begin{tabular}{lccc}
\hline Complications & $p$ & OR & $95 \% \mathrm{CI}$ \\
\hline Nephropathy (UACR) & & & \\
\hline $\begin{array}{l}\text { Normal } \\
\text { Abnormal }\end{array}$ & 0.284 & $\begin{array}{c}\text { Reference group } \\
1.93\end{array}$ & $0.58-6.46$ \\
\hline $\begin{array}{l}\text { Normal } \\
\text { Abnormal }\end{array}$ & 0.016 & $\begin{array}{c}\text { Reference group } \\
2.96\end{array}$ & $1.25-6.98$ \\
\hline
\end{tabular}

OR : Odds Ratio.

CI : Confidence Interval.

UACR : Urine Albumin Creatinine Ratio.

The simple regression analysis of microvascular complications in relation to DPN among the studied patients revealed an increased risk for the development of DPN in patients with abnormal fundus examination with a significant risk of 2.96 times (OR 2.96, 95\% CI 1.25-6.98).

\section{Discussion}

Diabetic Peripheral Neuropathy (DPN) is the most commonly reported long-term diabetic complication, affecting up to $50 \%$ of diabetic patients [11]. Prevalence rates of DPN varies from 5-100\%, [12] this wide range may reflect the diverse study population, different types of diabetes mellitus [13] .

In our study, 124 patients were selected from registered patients in Aden Diabetic Center; were DPN assessed by NSS and NDS, the prevalence of DPN was (60.48\%), in compared with other studies that used same scores in assessment, nearly similar prevalence were found by Borü et al., (60\%) [14] and by Mimi et al., (50.7\%) [15] while higher than that reported by Jarso et al., (48.2\%) [16] and Young et al., (28.5\%) [17], and less in compared with Nadir et al., (66.5\%) [18]. Prevalence of DPN in another studies done by Gunaid et al., [19] who depended on assessment of the peripheral neuropathy on subjective and objective criteria, as well 
Al-Washali et al., [20] who assessed by clinical scores were $(66.5 \%, 56.2 \%$ respectively).

Possible explanation of high prevalence of diabetic peripheral neuropathy in our study was that, $44.4 \%$ of the studied population had poor glycemic control $\mathrm{HbA}_{1 \mathrm{c}}>9$ while only $13.7 \%$ had good glycemic control $\mathrm{HbA}_{1 \mathrm{c}}<7$.

The mean age of our study population was $51.0 \pm 11.6$ years which was nearly equal to the mean age reported by Kiani et al., [21] (53.2 \pm 14.4 years), Wang et al., [22] (53.4 \pm 10.5 years) and AlWashali et al., [20] (53.5 \pm 11.1 years).

In the developing countries, the majority of diabetic patient are in the age range 45-64 years [23]. In the present study, a significant number of study population were in the age group (50-64) years $(56.5 \%)$, while the least frequent age group was patient $<20$ years $(1.6 \%)$. Similar results were obtained by Nadir et al., [18].

In this study, a significant relation was found between DPN and age of patient ( $p$ 0.009); neuropathy increased progressively with increasing age reaching maximum frequency of $90 \%$ in patient aged $>65$ years followed by $64 \%$ in patient aged (50-64) years. Moreover, DPN was absent in younger age groups $<20$ years, same significant association found in studies conducted by Young et al., [17] Boru et al., [14] and Mimi et al., [15]

In addition, the mean age of patients with DPN was significantly higher than that of patient without DPN (53.6 \pm 9.9 Vs. $46.9 \pm 12.8$ years respectively). Similar results were obtained by Kiani et al., (59.3 \pm 11.6 Vs. 48. $1 \pm 14.6$ years) [21] and Katulanda et al., in (62.1 \pm 10.8 Vs. $55.1 \pm 10.8$ years) [24]

The sex distribution in our study showed female preponderance $(56.5 \%)$ which is similar to female preponderance reported by Al-Washali et al., [20], in other studies observed that, male being at higher risk of DPN in the diabetic control and complication Trail [25] and although female population were greater $(64.3 \%)$, gender has non-significant impact on frequency of DPN in our study. The present observation was supported by Kasim et al., [26] Increasing educational level was linked with better health care and self-care knowledge and practice [27]. In the present study, DPN was significantly associated with patient's educational level ( $p 0.013)$, illiterate patients had the highest frequency of DPN $80 \%$ while highly educated subject appear to be protected from DPN with the least frequency $37.5 \%$. Our result is in agreement with Caliskan et al., [27]
In this study, the overall prevalence of DPN in T2D patients $(64.5 \%)$ was significantly higher than that in T1DM patients (35.3\%) ( $p$ 0.022). This high prevalence among T2D was also reported by others studies as Nadir et al., (69\%) [18], Al-Washali et al., (57.9\%) [20] and Kiani et al., [21]. This trend may be related to late diagnosis or the long prodromal period between the onset and the diagnosis of T2D. Our result is not similar to Jambart et al., [28] and Wang et al., [22] both determine T1D as a significant risk factor for DPN.

The mean duration of diabetes in this study population was $(8.47 \pm 6.8)$ years, which is similar to that reported by Mimi et al., from [15] $(8.49 \pm 7.33)$ years, Kiani et al., [21] (9.26 \pm 7.44$)$ years and AlWashali et al., [20] (7. $14 \pm 5.7$ ) years. The patients included in this study had diabetes duration ranging from 1 to 31 years, this wide range of duration was further subdivided into groups so that the proper analysis of the effect of increasing duration could be done. The present study found a significant ( $p$ 0.001) positive trend between duration of diabetes and the risk of DPN, were prevalence of DPN increased from $39.6 \%$ in patients with $<5$ years of diabetes duration to $80 \%$ in patients with 10-20 years diabetes duration, this trend was observed similarly in another prevalence studies as Jarso et al., [16] and Prasad et al., [29].

Cigarette smoking was found to be associated with an increased risk of DPN in some of the previous studies [30]. In the present study, however, no significant relationship was observed between DPN and current smoking (37.5\%). Wang et al., in [22], and Ali et al., [31] also found no significant relation between smoking and DPN. Most of our patients were nonsmokers (93.5\%), which may affect the result.

In the international literature, no adequate information available about Khat chewing and DPN. In our study, Khat chewing had nonsignificant effect on DPN (50\%). Our result is not similar to Ali et al., [31] where DPN was significantly associated with Khat chewing. The present data show that patients reported positive family history of DM were found to have higher frequency of DPN, as compared with those without a family history of diabetes mellitus (64.5\% Vs. $51.3 \%)$ but this relation was statistically non-significant, likewise, Janghorbani et al., [32] and Al-Kaabi et al., [33]reported similar results. However, JI Na et al., [34]and Kasim et al., [26] found that family history of DM is a significant predictor for DPN. Moreover, Amjad et al., [35] found that the prevalence of diabetic complication was low among patient with 
family history of diabetes as compared to diabetic patient without family history.

$\mathrm{HbA}_{1 \mathrm{c}}$ being the highest among our patients with poor glycemic control (65.5\%). However, this relation was statistically non-significant ( $p$ 0.197), similar findings were observed in different studies as Janghorbani et al., [32] and Wang et al., [22] Possible explanation is that single blood result of $\mathrm{HbA}_{1 \mathrm{c}}$ is a poor indicator of the overall diabetic control.

In the current study, patients treated with insulin and oral anti-diabetic drugs had the highest frequency of DPN (80\%), however, type of therapy had non-significant impact on the development of DPN ( $p$ 0.119). Similar results were observed in other studies as JI Na et al., [34] and Al-Kaabi et al., [33] while not in agreements with other studies as Tamer et al., [36] and Davis et al., [37] all these studies associate DPN with insulin use. Some of those studies postulated that exogenous insulin therapy might be associated with DPN through an exacerbation of obesity, fluid retention, hypertension and hyperlipidemia or even insulin induced neuritis [32]. In our study, we found that diabetic patient with dyslipidemia had significantly higher risk of diabetic peripheral neuropathy $(71.4 \%)(p$ $0.011)$. Our results were in accordance with many other studies as Jambart et al., (59\%) [28], Preeti et al., (58\%) [38] . It also correspond to Won et al. [39]. A prospective study of patients with idiopathic neuropathy confirmed a higher prevalence of hyperlipidemia than impaired glucose tolerance or hypertension, also suggesting that hyperlipidemia is an essential factor underlying nerve injury [40]

In our study, despite the existence of a positive association between hypertension and DPN, it was statistically not significant (66.7\% Vs. 55.2\%). Our result is similar to Al-Washali et al., (64\% Vs. 53\%) [20]. It is also in agreement with Borï et al., [14] and Shaw et al., [40]. Hypertension had emerged as a significant risk factor for DPN in other studies as Prasad et al. [29] .

Patients presenting with cardiovascular disease are at increased risk of DPN [34]. In our study, both patients with and without IHD show high frequency of DPN (53.8\% Vs. 61.3\%), although this association was not significant $(p>0.05)$. Our findings were in agreement with Nadir et al., [18] and JI Na et al., [34] Nevertheless, it is not similar to Jambart et al., [28] and Janghorbani et al., [32]. Data from the current study suggested that abdominal obesity defined by waist circumference was significant with DPN ( $p$ 0.001). These findings were in agree- ment with. Ziegler et al., study, [41] who reported a positive association between waist circumference and DPN as well as Wang et al., [22] and AlMahroos et al., [42]. However, in Tapp et al., study [43] and Bansal et al., in their studies, [13] found no significant association between waist circumference and DPN. Insulin resistance is more strongly related to abdominal obesity than general obesity. Previous studies suggest that insulin resistance is associated with DPN and autonomic function impairment [44].

BMI is a standard unit for quantifying obesity [45]. Our study found that, patients with DPN had higher mean (BMI) than patients without DPN ( $p$ 0.036). Similar finding was observed with Tesfaye in prospective complications study, [46] Jambart et al., [28] and Al-Mahroos et al., [42] where obesity was a significant risk factor for DPN. However, Katulanda et al., [24] found that obese patients had lower prevalence of DPN compared with nonobese patients.

It has been widely recognized that poor glycemic control is an important risk factor for neuropathy [46]. In this study, patients with DPN had higher mean ${ }_{\mathrm{HbA}_{1 \mathrm{c}}}$ levels compared with those without neuropathy, but this was no statistically significant, this finding supported the same observations in many studies as Bansal et al., [13], Booya et al., [47] and Partanen et al., [48]. Yüksel et al., [49] where $\mathrm{HbA}_{1 \mathrm{c}}$ was significantly associated with DPN. This may be because most of patients were already on treatment at the time of the study (98.5\%).

In this study, patients with DPN had higher fasting blood sugar levels compared with those without neuropathy, but this was not statistically significant. A similar finding was observed in several studies as in Zhang et al., [50] and Pradeepa et al., [51]. Moreover, the Fremantle Diabetes Study that has done in Australia [18], Wang et al., in [22] and Partanen et al., [48] reported that DPN was significantly related to increase fasting blood sugar.

In this study, participants with higher levels of urea had high percentage of DPN with nonsignificant relation $(p>0.05)$. Our result is in agreement with Wang et al., in [22] and JI Na et al., [34] while Aguiar et al., [52] and Zhang et al., [50], were they found that, patients with DPN had higher urea compared to patients without DPN but with significant association. In addition, our study showed that creatinine level had non-significant association with DPN ( $p$ 0.231). This finding correspond to JI $\mathrm{Na}$ et al., [34] and Aguiar et al., [52] in contrast, 
Wang et al., from [22] and Zhang et al., [53] reported that higher creatinine level was as a significant risk factor for DPN.

The present study has accounted for lipid profile as tested for its association with DPN, were mean of lipid profile showed no significant difference between patient with and without DPN. Concordant results were found by other studies as JI Na et al., [34] and Davis et al., [37].

Relation between the prevalence of DPN in individuals with and without retinopathy was also studied to establish a relation between the two. In the present study, patients with non-proliferative and proliferative retinopathy had significantly high frequency of DPN $(80 \%$ and $71 \%)$ respectively compared with patients with no retinopathy $(52 \%)$ ( $p$ 0.035).Similarly, Ali et al., [31] and Won et al., [39] concluded that neuropathy was seen more in patients with coexisting retinopathy. JI Na et al., [34]. Abougalambou et al., [53] and Janghorbani et al., [32] proved retinopathy to be an independent risk factor for diabetic neuropath.

The association of DPN with nephropathy has been variably present $[28,39]$. In this study we found a numerical higher frequency of DPN among patients with micro-albuminuria and macroalbuminuria (71\% and $100 \%)$ more than patients with no albuminuria (58.7\%), but we couldn't identify it as significant predictor ( $p$ 0.473). Our result was in concurrent with Pradeepa et al., [51] and Barbosa et al., [54] but it is not similar to Jambart et al., [28] where nephropathy emerged as a significant risk factor for DPN. The high frequency of DPN among patients with macro-albuminuria is duo to small sample size. Only one patient in our study had macro-albuminuria and DPN. This may be explained by the fact that patients with more severe renal impairments were excluded from the study. The association between DPN with albuminuria is of potential importance, UACR is a sensitive indicator of DPN even with mild abnormal rang [51]. On the other hand this association may be used to support the micro-vascular hypothesis in the pathogenesis of diabetic neuropathy in that micro-albuminuria, as a marker for early nephropathy, has undoubted micro-vascular etiology [47].

Simple logistic regression analysis showed an expected pattern of association for many variables with DPN. These variables are age; educational level, abdominal obesity, T2D, longer DM duration,dyslipidemia and retinopathy. In multivariate analysis, fewer remain independently associated with DPN. In the current study, the odds of having neuropathy were greater among those with low educational level compared with those completed university education. This concurs with many studies conducted elsewhere lower level of education may be a marker of lower socioeconomic status, which in turn may be associated with poorer access to health care services and self-care practices [55]. Consistent with prior studies, the present study confirms the well-established association between the prevalence of DPN and duration of diabetes as an independent risk factor [56] in all these studies, development of peripheral neuropathy showed a progressive increase with increased duration of diabetes. The independent association observed between DPN and the presence of dyslipidemia have previously described [49]. As well as the independent association between abdominal obesity and DPN [57].

\section{Conclusion and Recommendation:}

Based on the findings of this study Illiteracy, abdominal obesity, longer duration of diabetes and dyslipidemia are most important predictors of diabetic peripheral neuropathy. We recommended for more adherence to strict glycemic control as well raising the education level with good awareness about diabetic mellitus as the key in delay development of diabetic neuropathy and it's complication.

\section{References}

1- ALBERTI K.G. and ZIMMET P.Z.: Definition, diagnosis and classification of diabetes mellitus and its complications. Diabet. Med., 15 (7): 539-53, 1998.

2- BOULTON A.J.: The diabetic foot. Sci. Dierct., 3 (34): 87-90, 2006.

3- Report and recommendations of the San Antonio conference on diabetic neuropathy. Neurology, 37 (7): 1000-4, 1988.

4- BOULTON A.J., VILEIKYTE L., RAGNARSONTENNVALL G. and APELQVIST J.: The global burden of diabetic foot disease. Lancet, 366: 1719-24, 2005.

5- VESNA DERMANOVIC DOBROTA, PERO HRABAC DINKO SKEGRO, RANKO SMILJANIC, et al.: The impact of neuropathic pain and other comorbidities on the quality of life in patients with diabetes. Health Qual., 12: 171, 2014.

6- ZOCHODNE D.W.: Diabetes mellitus and the peripheral nervous system: Manifestations and mechanisms. Muscle \& Nerve, 36 (2): 144-66, 2007.

7- HARRY L. HÉBERT, *ABIRAMI VELUCHAMY, NICOLA TORRANCE and BLAIR H. SMITH: Risk factors for neuropathic pain in diabetes mellitus, 158 (4): 560-8, 2017.

8- MAMTA JAISWAL, JASMIN DIVERS, DANA DABELEA and SCOTT ISOM: Prevalence of and Risk Factors 
for Diabetic Peripheral Neuropathy in Youth With Type 1 and Type 2 Diabetes. Diabetes Care, 40: 1226-32, 2017.

9- HERNDON R.M. : Introduction to clinical neurological scales. Editor. Handbook of Neurologic Rating Scales. New York: Demos Vermand, 1-6, 1997.

10- PICON A.P., ORTEGA N.R., WATARI R., SARTOR C. and SACCO I.C.: Classification of the severity of diabetic neuropathy: Logic. Clinics, 67 (2): 151-6, 2012.

11-VINIK A. and MEHRABYAN A.: Diabetic neuropathies. Medical Clinics of North America, 88 (4): 947-99, 2004

12- BANSAL D., GUDALA K., MUTHYALA H., ESAM H.P., NAYAKALLU R. and BHANSALI A.: Prevalence and risk factors of development of peripheral diabetic neuropathy in type 2 diabetes mellitus. Journal of Diabetes Investigation, 5 (6): 714-21, 2014.

13- MAYER T., DAVIS E.J., et al.: Type 1 diabetes vs type 2 diabetes diagnosed during childhood and adolescence with complications during teenage years and young adulthood. JAMA, 31 (7): 825-35, 2017.

14- BORÜ T., ALP R., SARGIN H., KOÇER A., SARGIN M., LÜLECI A., et al.: Prevalence of peripheralneuropathy in type 2 diabetic patients attending a diabetes center in Turkey. Endocrine Journal, 51 (6): 563-7, 2004.

15- MIMI O., TENG C. and CHIA Y.: The prevalence of diabetic peripheral neuropathy in an outpatient setting. The Medical Journal of Malaysia, 58 (4): 533-8, 2003.

16- JARSO G., AHMED A. and FELEKE Y.: The prevalence, clinical features and management of periphral neuropathy among diabetic patients in Tikur Anbessa, Addis Ababa, Ethiopia. Ethiopian Medical Journal, 49 (4): 299-3 11, 2011.

17- YOUNG M., BOULTON A., MacLEOD A., WILLIAMS D. and SONKSEN P.: A multicentre study of the prevalence of diabetic peripheral neuropathy in the United Kingdom hospital clinic population. Diabetologia, 36 (2): 150-4, 1993.

18- ALI F. NADIR: Clinical charictristics of diabetic patient admitted to al Gamhouria Teaching Hospital. Aden University, (unpuplished Master Thesis), 2005.

19- GUNAID A.A., EL-KHALLY F.M., HASSAN N.A. and MUKHTAR E.: Demographic and clinical features of diabetes mellitus in 1095 Yemeni patients Ann. Saudi Med., 17 (4): 402-9, 1997.

20- AL-WASHALI A., AZUHAIRI A., HEJAR A. and AMANI Y.: Prevalance and associated risk factors of diabetic peripheral neuropathy among diabetic patients in national center of diabetes in Yemen. International Journal of Public Health and Clinical Sciences, (1): 141-50, 2014.

21- KIANI J., AZIZKHANI H. and KOSARIFARD S.: The prevalence and associated risk factors of peripheral diabetic neuropathy in Hamedan, Iran. Archives of Iranian Medicine, 16 (1): 17-9, 2013.

22- WANG D.D., BAKHOTMAH B.A., HU F.B. and ALZAHRANI H.A.: Prevalence and correlates of diabetic peripheral neuropathy in a Saudi Arabic population: A crosssectional study. PloS One, 9 (9): 106-35, 2014.

23- WILD S.R.G. and GREEN A. SA K.H.: Global prevalence of diabetes: Estimates for the year 2000 and progections for 2030. Diabetes Care, 27 (5): 1047-53, 2004.
24- KATULANDA P., RANASINGHE P., JAYAWARDENA R., CONSTANTINE G.R., SHERIFF M.R. and MATTHEWS D.R.: The prevalence, patterns and predictors of diabetic peripheral neuropathy in a developing country. Diabetology J., 4 (1): 1-21, 2012.

25- The effect of intensive treatment of diabetes on the development and progression of longterm complications in insulin-dependent diabetes mellitus Diabetes Control Complications Trial Research Group. N. Engl. J. Med., 329 (14): 977-86, 1993.

26- KASIM K., AMAR M., EL-SADEK A.A. and GAWAD S.A.: Peripheral neuropathy in type -II diabeticpatients attending diabetic clinics in Al-Azhar University Hospitals, Egypt. International Journal of Diabetes Mellitus, 2 (1): 20-3, 2010.

27- ÇALISKAN D., OZDEMIR O., OCAKTAN E. and IDIL A.: Evaluation of awareness of diabetes mellitus and associated factors in four health center areas. Patient Education and Counseling, 62 (1): 142-7, 2006.

28- JAMBART S., AMMACHE Z., HADDAD F., YOUNES A., HASSOUN A., ABDALLA K., et al.: Prevalence of painful diabetic peripheral neuropathy among patients with diabetes mellitus in the Middle East region. Journal of International Medical Research, 39 (2): 366-77, 2011.

29- PRASAD V., BAZROY J. and SINGH Z.: Prevalence and determinants of peripheral neuropathy among diabetics in a rural cum costal area of Villupuram district. Nadu. International Journal of Research in Medical Sciences, 3 (10): 25, 2017.

30- D'SOUZA M., KULKARNI V., BHASKARAN U., AHMED H., NAIMISH H. and PRAKASH A.: Diabeticperipheral neuropathy and its determinants among patients attending a tertiary health care centre in Mangalore, India. Journal of Public Health Research, 4 (2): 450, 2015.

31- ALI M.S.: Prevalence of peripheral neuropathy in Type 2 diabetes among Yemeni patients. Khartoom University, Sudan (Un puplished Doctoral Dissertation National Information center. Yemen, 3-8, 2008.

32- JANGHORBANI M., REZVANIAN H., KACHOOEI A., GHORBANI A., CHITSAZ A., IZADI F., et al.: Peripheral neuropathy in type 2 diabetes mellitus in Isfahan, Iran: Prevalence and risk factors. Acta Neurologica Scandinavica, 114 (6): 384-91, 2006.

33- AL-KAABI J., AL MASKARI F., ZOUBEIDI T., ABDULLE A. and SHAH S.: Prevalence and determinants of peripheral neuropathy in patients with type 2 diabetes attending a tertiary care center in the United Arab Emirates. J. Diabetes Metab., 5 (3): 346: 2, 2014.

34- JI N., ZHANG N., REN Z., JIA K., WANG L., NI J., et al.: Risk factors and pain status due to diabetic neuropathy in chronic long-term diabetic patients in a Chinese urban population. Chinese Medical Journal, 125 (23): 4190-6, 2012.

35- AMJAD H., SALMAN M., FAZEL R., NURJIS F., SHAFAQAT A. and QURESHI J.A.: Diabetic Complications: Influence of Age, Sex, Family History, Duration, Glycémie Control and Obesity. Journal of Biological Sciences, 2 (10): 710-4, 2002.

36- TAMER A., YILDIZ S., YILDIZ N., KANAT M., GUNDUZ H., TAHTACI M., et al.: The prevalence of neurop- 
athy and relationship with risk factors in diabetic patients: A single-center experience. Medical Principles and Practice, 15 (3): 190-4, 2006.

37- DAVIS T., YEAP B., DAVIS W. and BRUCE D.: Lipidlowering therapy and peripheral sensory neuropathy in type 2 diabetes: The Fremantle Diabetes Study. Diabetologia, 51 (4): 562-6, 2008.

38- PREETI P. PAWDE1 R.R.T., RENISH R.K.2, RESMI R.U.2 and VIVEK M.R2.: Prevalance and risk factors of diabetic peripheral neuropathy among Type 2 . International Journal of Medical Science and Public Health, 1 (2): 736, 2013.

39- WON J., KWON H., KIM C., LEE J., PARK T., KO K., et al.: Prevalence and clinical characteristics of diabetic peripheral neuropathy in hospital patients with type 2 diabetes in Korea. Diabetic Medicine, 9: 290-6, 2012.

40- SHAW J.E., HODGE A.M., De COURTEN M., DOWSE G.K., GAREEBOO H., TUOMILEHTO J., et al.: Diabetic neuropathy in Mauritius: Prevalence and risk factors. Diabetes Research and Clinical Practice, 42 (2): 131-9, 1998.

41- ZIEGLER D., RATHMANN W., DICKHAUS T., MEISINGER C., MIELCK A.: Prevalence of polyneuropathy in pre-diabetes and diabetes is associated with abdominal obesity and macroangiopathy. Diabetes care, 31 (3): 464 9, 2008.

42- AL-MAHROOS F. and AL-ROOMI K.: Diabetic neuropathy, foot ulceration, peripheral vascular disease and potential risk factors among patients with diabetes in Bahrain: Annals of Saudi Medicine, 27 (1): 25-31, 2007.

43- TAPP R., SHAW J., De COURTEN M., DUNSTAN D.W., WELBORN T. and ZIMMET P.: Foot complications in type 2 diabetes: An Australian population-based study. Diabetic Medicine, 20 (2): 105-13, 2003.

44- KATSILAMBROS N.L., BOULTON A.J., TENTOLOURIS N., KOKKINOS A. and LIATIS S.: Autonomic neuropathy in diabetes mellitus and obesity: An update. Journal of Diabetes Research, 25 (14): 10-9, 2011.

45- World Health Organization, Obesity: Preventing and managing the global epidemic: WHO Technical Report Series, 2000.

46- TESFAYE S., STEVENS L., STEPHENSON J., FULLER J., PLATER M., TIRGOVISTE C., et al.: Prevalence of diabetic peripheral neuropathy and its relation to glycaemic control and potential risk factors: The Eurodiab Iddm Complications Study. Diabetologia, 39 (11): 137-84, 1996.

47- BOOYA F., BANDARIAN F., LARIJANI B., PAJOUHI M., NOORAEI M. and LOTFI J.: Potential risk factors for diabetic neuropathy: A case control study. BMC Neurology, 5 (1): p. 24, 2005.

48- PARTANEN J., NISKANEN L., LEHTINEN J., MERVAALA E., SIITONEN O. and UUSITUPA M.: Natural history of peripheral neuropathy in patients with non-insulin-dependent diabetes mellitus. N. Engl. J. Med., 333 (2): 89-94, 1995.

49- YÜKSEL KAPLAN S.K., HATICE KARAER ÜNALDI and ÜNAL ERKORKMAZ: Risk Factors For Diabetic Polyneuropathy. Archives of Neuropsychiatry, 51 (1): 114, 2014.

50- ZHANG Y., JIANG Y., SHEN X. and YAN S.: Can both normal and mildly abnormal albuminuria and glomerular filtration rate be a danger signal for diabetic peripheral neuropathy in type 2 diabetes mellitus? Neurological Sciences, 38 (8): 1381-90, 2017.

51- PRADEEPA R., REMA M., VIGNESH J., DEEPA M., DEEPA R. and MOHAN V.: Prevalence and risk factors for diabetic neuropathy in an urban south Indian population: The Chennai Urban Rural Epidemiology Study Diabetic Medicine, 25 (4): 407-12, 2008.

52- AGUIAR P.C.M., DELLA COLETTA M.V. and De SOUZA J.J.S.: The association of dyslipidemia and peripheral diabetic neuropathy: The influence of urea. Diabetology \& Metabolic Syndrome, 1, (2): 2, 2016.

53- ABOUGALAMBOU S.S.I. and ABOUGALAMBOU A.S. Explorative study on diabetes neuropathy among type II diabetic patients in Universiti Sains Malaysia Hospital. Diabetes \& Metabolic Syndrome: Clinical Research \& Reviews, 6 (3): 167-72, 2012.

54- BARBOSA A., MEDINA J., RAMOS E. and BARROS H.: Prevalence and risk factors of clinical diabetic polyneuropathy in a Portuguese Primary Health Care Population, 2001.

55- BRUCE S.G. and YOUNG T.K.: Prevalence and risk factors for neuropathy in a Canadian First Nation community. Diabetes Care, 31 (9): 1837-41, 2008.

56- GILL H., YADAV S., RAMESH V. and BHATIA E.: A prospective study of prevalence and association of peripheral neuropathy in Indian patients with newly diagnosed type 2 diabetes mellitus. Journal of Postgraduate Medicine, 60 (3): 270-5, 2014.

57- AUBERT C., MICHEL P.L., GILLERY P., JAISSON S., FONFREDE M., MOREL F., et al.: Association of peripheral neuropathy with circulating advanced glycation end products, soluble receptor for advanced glycation end products and other risk factors in patients with type 2 Diabetes, 3 (08): 679-85, 2014. 


\section{إنتشاروعوامل الحطر للإعتلال العصبى المحيطى بين مرضى السكرى

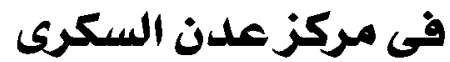

الخلفية: الإعتلال العصبى المحيطى هو آحد المضاعفات الهامة للآوعية الدقيقة لمرضى السكرى ويعتبر مساهماً رئيسياً فى تقرح القدم وبتر الآطراف السفلية بين مرضى السكرى ولها تآثير سلبى بارز على جودة العياة.

الهدف: هذه الدراسة تهدف إلى تحديد مدى إنتشار الإعتلال العصبى المحيطى وعوامل الخطورة بين مرضى السكرى المتردلون على مركز عدن السكرى فى محافظة عدن - اليمن.

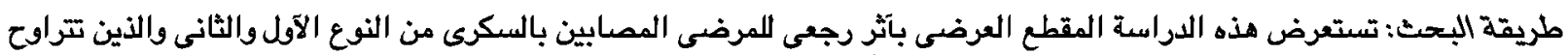

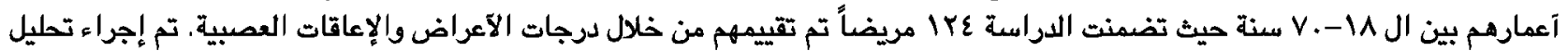
الإحصاء الوصفى والإنحدار اللوجستى.

النتائج: آظهرت النتائج القائمة على آساس درجات الآعراض والإعاقات العصبية إن إنتشار الإعتلال العصبى المحيطى لمرضى السكرى كان

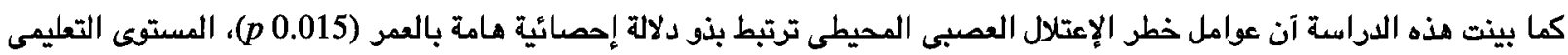

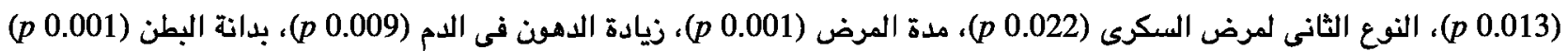

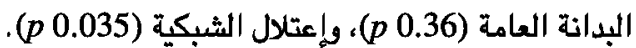

كذلك آظهرت هذه الدراسة آن إرتفاع ضغط الدم، زيادة نسبة الهيموجلوبين السكرى وقجود بيلة الآلبومين يزيد من نسبة الإصابة بالإعتلال

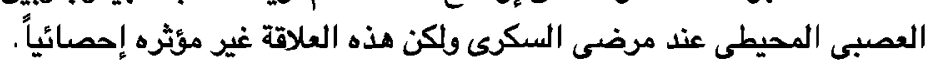

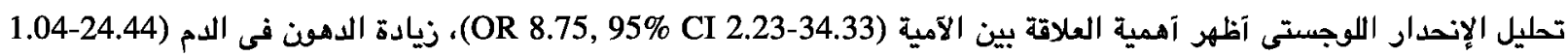

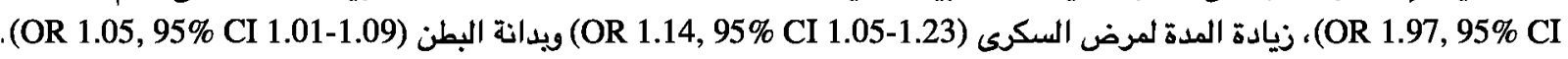
الإستتاج:وجدت الدراسة آن النسبة مرتفعة الإنتشار للإعتلال العصبى المحيطى بوجود عوامل الخطوره بين المرضى اللذين يعانفن من الآمية، زيادة نسبة الدهون بالدم، زيادة مدة المرض بالسكة السكرى والسمنة في منطقة البطن. 